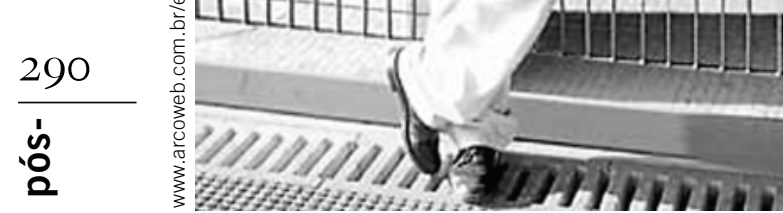

\section{JoÃo Walter Toscano}

Júlio Roberto Katinsky

\section{UMA FESTA DA CRIATIVIDADE}

Sessenta anos. Conheci João Toscano no cursinho preparatório para o vestibular (1951), quando ele fez uma caricatura com giz de nosso professor de "análise matemática", Di Tullio. Lembro-me bem do professor que nos transmitiu um grande respeito pela matemática moderna, espantado em reconhecer-se na antiga lousa preta em um de seus momentos característicos.

Quando entramos na FAU, em 1952, a Escola (alunos e alguns professores) sofria os efeitos de uma derrota da greve do ano anterior, quando Anhaia Mello, seu diretor, sentiu-se desprestigiado, pois o Conselho Universitário, em uma manobra maliciosa, recusara os nomes de prestigiosos arquitetos, entre eles Oscar Niemeyer (sob a estúpida insinuação de aliciamento político em relação aos inocentes jovens) e, ainda mais grave, colocara em seu lugar figuras modestíssimas de artistas e arquitetos que não gozavam de destaque nem mesmo no então ultraprovinciano meio paulistano.

Entramos, então, em uma escola dominada pelo derrotismo (e desânimo) entre os alunos e desconfiança generalizada em relação aos professores.

Nossa formação se fez nesse ambiente difícil, no qual a única vertente de discussão seria o que deveria ser uma escola ideal de arquitetura, como a mitológica Bauhaus da Alemanha pré-nazista, ou as notícias longínquas de notáveis arquitetos modernos nos Estados Unidos, na Europa e no Brasil.

Assim, atiramo-nos a uma autoformação, praticamente a partir do segundo ano de nossa matrícula. Toda essa geração procurou um autodidatismo paralelo à educação formal oferecida pela escola, em livro (Bruno Zevi e sua exaltação de F. L. Wright, Giedion e sua exaltação de Gropius e Le Corbusier), em escritórios, visitando por conta própria canteiros de obras, em concursos de capas, cartazes e, especialmente, o concurso para estudantes de arquitetura da Bienal de São Paulo, desde a primeira. Entre os mestres que nós, em nossa ingenuidade, elegemos, dois arquitetos 
se destacam: João Vilanova Artigas, cuja obra visitamos afetuosamente, desde as casas até suas obras urbanas mais destacadas. E Luis Saia, que, no SPHAN do qual era diretor, de todo o sul até o sudeste de Goiás e Mato Grosso, sempre nos recebeu pacientemente. Foi por ele que conhecemos as obras relevantes do ponto de vista da excelência artística; as paulistas em primeiro lugar, e brasileiras e mundiais em seguida. Lembro-me quando João Toscano, estagiando no escritório do arquiteto Miguel Badra, mostrou para os colegas o desenho de um azulejo que iria depois guarnecer o edifício, no início da avenida Paulista. Até hoje, quando passo em frente e vejo os azulejos aplicados, lembro-me daquela vitória que significava participar de uma obra de arquitetura, real, não um mero exercício escolar, como nós víamos.

É claro que hoje há mais de um livro apresentando a obra do arquiteto, com suas obras mais destacadas. Mas gostaria de mostrar, aqui, o crescimento contínuo, que pude presenciar. Vou fixar, então, em duas obras, a Faculdade de Filosofia do Patrocínio, em Itu, e a Estação 13 de maio, em Santo Amaro.

$\mathrm{Na}$ Faculdade, uma de suas primeiras obras como arquiteto, que, aliás, ele aproximou a uma vista do conjunto do Pedregulho de Affonso E. Reidy em sua tese de doutoramento, João usou, como textura de um muro de separação, sem função estrutural, grandes seixos rolados do rio Tietê $(10 \mathrm{~cm})$, que, pelo inusitado da seleção, adquiriu uma graça notada por todos os arquitetos que a visitaram, notadamente Fernando Távora, o arquiteto do Porto e seu amigo de longa data. Registro esse fato porque me parece uma característica do artista: explorar a circunstância em sua espontânea carga poética.

Uma obra de seu período mais maduro, a Estação 13 de maio, é uma parada de trem metropolitana, em Santo Amaro, e apresentava uma dificuldade aparentemente intransponível: situa-se paralela e rente a uma via de tráfego intenso, marginal do rio Pinheiros, entre a Estação elevatória de Traição e a Barragem da Billings. Já escrevi há algum tempo para a feliz solução de, através da passarela (que aproveita o desnível da rua e o leito ferroviário), atingir a gare por um andar acima, que permitiu não só um acesso fácil e desimpedido, mas criou uma área de estar para desfrute da paisagem em torno.

Mas quero também chamar a atenção para a estrutura metálica construída com pórticos de aço corten de desenho curvo recortado em chapa. É certo que a estrutura poderia ser resolvida com os perfis correntes em duplo T ou I, mas seu desenho inusitado e caprichoso propiciou outras estruturas de outros arquitetos, trabalhando o aço com a mesma liberdade que só se acreditava possível com concreto.

Mas não posso deixar de destacar uma última contribuição do arquiteto: durante seu longo percurso preocupou-se com a preservação do patrimônio artístico caipira, especialmente localizado em Itu, tanto das pinturas do Padre Jesuino do Monte Carmelo como da organização barroca da cidade, justificando afirmação de "cidadão prestante" emprestada do poeta máximo de nossa língua:

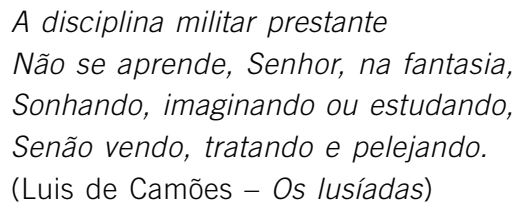


1 Uso a palavra

generosidade em seu sentido original. Segundo Houais, a palavra deriva do grego genos - origem nascimento - criação.

2 Odileia Helena Setti Toscano - arquiteta formada na FAU, dedicouse também como ilustradora, pintora, paisagista e colaboradora do marido, além de notável docente da FAUUSP.

3 Massayochi Kamimura, aluno de João Toscano na Escola Técnica Getulio Vargas - arquiteto formado pela Escola de Arquitetura Mackenzie, colaborador durante mais de 40 anos no Escritório de João Toscano.
É reconhecido por muitos que obras de arquitetura, diferente de outras artes, são sempre produto coletivo. Ou seja, muitos engenhos concorrem, por feliz coincidência, para que uma edificação exiba sua excelência. Mesmo em pequenas obras, quando parece ser produto de uma única mente, podemos facilmente descobrir antecedentes ou aquilo que se chama "inspiração" ou "homenagem".

Podemos notar é que não tanto as obras de arquitetura são produto coletivo, mas são também produto da generosidade ${ }^{1}$ do viver coletivo, no qual o viver individual se ampara em inúmeras individualidades. Então, podemos suspeitar que qualquer obra de arquitetura acolhe e exibe, em sua realidade concreta, a mais íntima alegria da criação humana: trata-se sempre de uma festa da criatividade. Vejo, assim, nessa trajetória de mais de 50 anos de João Walter Toscano, a participação conjunta de pelo menos duas pessoas muito próximas dele, e, por intermédio delas, de todas as outras: Odileia Helena² sua companheira de sempre, afetiva e intelectualmente, e o arquiteto Massayochi ${ }^{3}$, colaborador de mais de 40 anos. É um milagre humano que se renova em todos aqueles que reconhecem, nas obras desse arquiteto, seu endereço essencialmente humano.

\section{Júlio Roberto Katinsky}

Professor titular do Departamento de História da Arquitetura e Estética do Projeto. 